\title{
An Assessment of Challenges and Prospects of the Women's Entrepreneurs in Hawassa City, Southern Nation Nationalities and People, Ethiopia
}

\author{
Tolasa Tafa Wami \\ Department of Management, College of Finance and Management Studies, Oromia State University, Batu \\ Oromia, Ethiopia \\ Temam Gebu Duressa \\ Department of Public Administration and Development Management, College of Business and Economics, \\ Wolaita Sodo University, Wolaita Sodo, Ethiopia
}

\begin{abstract}
Women entrepreneur plays a decisive role in the economic and social development of the country. In spite of their position still, they are facing a range of challenges like lack of access to capital, inadequate managerial and marketing skills and their contribution is not yet recognized. Thus, this study aimed to assess the challenges and prospects of women's entrepreneur in Hawassa city. A graphic research design was conducted. Simple random sampling was used to select 42 women out of the total population. Both primary and secondary source of data was used. Primary data was collected using a scheduled questionnaire and structured interview. Regular supervision and follow up was made. The SPSS software version 20 was used to code, compile, and analyze data. Multivariate analysis was used to see the effect of the independent variable on the outcome variable. The finding of the study found that poor managerial and marketing skills, inexperience, and insufficient business related training were among the significant hampers of women entrepreneurs in Hawassa city. The result of the study also showed that educational background, market problem, lack of premises and lack of collateral were strongly associated with women entrepreneur at a p-value less than 0.05 . Women who have collateral to access credit were about four times more likely to participate in business than women who do not have collateral (AOR 3.914 (95\% CI ((0.370-41.394). Thus, it is recommended that the government should work to strengthen women entrepreneur via providing various skills training, finance support, business-oriented information and advising services.
\end{abstract}

Keywords: Women, entrepreneur, challenges, prospects, Hawassa, Ethiopia.

DOI: $10.7176 / \mathrm{EJBM} / 12-10-04$

Publication date: April $30^{\text {th }} 2020$

\section{INTRODUCTION}

Women entrepreneurship development is one of the crucial issues of contemporary development agenda in many developing countries. Women entrepreneur can be defined as a person who is alone or with one or more partners who started or inherited a business, eager to take financial, administrative, social risks and responsibilities, and participating in day-to-day management activities (Ulusay de Groot, 2001). The growing involvement of women in entrepreneurial activities in the last few decades has added a new dimension in the socio-economic structure of developing countries; women entrepreneurs are directly contributing to the national economy (Nasima and Alam, 2014). Women entrepreneur is also a tool to empower women both economically and socially. This empowerment consists of access to the material, human and social resources that are necessary to make strategic choices in their life (Zewde and Associates, 2002); thereby experiencing a more favorable level of social recognition, which will subsequently enhance their economic status (Sonfield et al., 2013). Furthermore, it is the new engines to the economic growth and the rising stars for women to bring their prosperity and welfare. In addition, it is an untapped source for economic growth and development. As a result, nowadays in developing countries, the attention to women entrepreneur has been increasing to a great extent and the focus on this untapped source of growth seem to be indispensable. It also became an emerging issue for development practitioners and policymakers (Vossenberg, 2013). Ethiopia is a country, which approximately has a population of 100 million. Of which women make up more than $50 \%$ of the population. The deployment of these women resource is mandatory through involving diverse activities that assist countries social and economic development. However, the participation of women has been under severe obstacles both at the operation and at the startup level. Some of the most critical constraints raised at different forms include lack of capital, insufficient entrepreneurial, managerial and technical training and experience, economic and technological problems (Saravanan et al., 2014). 


\section{Statement of the problem}

Women entrepreneurs play an essential role in the economy. Their products and services contribute to GDP growth. Women entrepreneurs also generate income and employment for many. Women have been disadvantaged in accessing not only material resources like credit and other property but also in obtaining social resources such as education, information and modern technology. All of these factors have negative implications for the type of enterprises that women are engaged in. Some recently conducted studies (Amha, 2002) showed that women involved in microenterprises started their business to overcome the challenges of poverty and its consequences. Women entrepreneurs in poor countries suffer from gender discrimination in society and laws, underdeveloped enterprise culture, an inadequate support system for businesses and weak markets and infrastructure. Generally, women-owned businesses are concentrated in the low growth segment, face constraints such as poor access to finance, lack of business development services and business networks, limited exposure to business management experience and the challenges of juggling business with household and family responsibilities. The women entrepreneurs in Ethiopia including Hawassa city also face many challenges like complexity in obtaining a loan from commercial banks, bankruptcy, shortage of technical skills, poor managerial skills, and low level of education (Bekele and Worku, 2008). The family members and the societies are reluctant to stand beside women entrepreneurs. Social, economic and family obligations are among the factors that impede women entrepreneur in Hawassa city. The other obstacles to women entrepreneur are a market-oriented risk, which comprises a lack of information about the market, and lack of women mobility makes the women market dependent on middleman indispensable. Moreover, since most women are not looking for up to date information, they find it difficult to capture the market and make their products popular. About women entrepreneur prospects, currently, women have involved considerably in the social and economic development via industrialization, urbanization along with education and awareness. This brings generous opportunities for the nation, society and the family. Setting up their own business not only makes them self-sufficient and self-dependent but also enables them to create their own social identity. It also helps women to achieve work-life balance and contributed to the satisfaction of their customers by involving themselves in the innovation of the products (Gorgievski et al., 2011). For instances, in the U.S., 1.5 trillion dollars' worth of sales is generated by more than 9 million firms owned by the women entrepreneurs. The women in both developed and developing countries are participating in the manufacturing, service and trading sector and the economic development of the nation; the role of a women entrepreneur has become significant. Hence, this study aimed to examine challenges and prospects of women entrepreneur in Hawassa city, Southern, Nation, Nationalities and People, Ethiopia.

\section{MATERIALS AND METHODS}

\section{Study setting}

The study used an explanatory research design. An illustrative type of research is used to see causal links between the independent and dependent variables that pertain to the research problem this study conducted at Hawassa Arab sefar sub-city. Hawassa is a capital city of Southern Nation, Nationalities and People Region and it is located at a distance of $275 \mathrm{~km}$ to the south of Addis Ababa, the capital city of Ethiopia.

\section{Sources population and sample size determination}

There are 24 women entrepreneur in Hawassa, 'Arab sefar' subcity. These women's businesses consist of 120 members, which contain a mix of women of various ages. A sample of 42 women entrepreneurs was taken for the study using simple random sampling. These 42 actual respondents were taken as a sample to represent the total study population (Kothari, 2014).

$$
\mathrm{n}=\frac{Z^{2} \times p \times q \times N}{e^{2}(N-1)+Z^{2} \times p \times q}=\frac{1.64^{2} \times 0.5 \times 0.5 \times 112}{0.05^{2}(112-1)+1.64^{2} \times 0.5 \times .5} \approx 42
$$

Where: $\mathrm{N}=$ Population Size, $\mathrm{n}=$ sample Size, $\mathrm{p}=$ Proportion of success, $\mathrm{e}=$ Margin of Error $(5 \%), \mathrm{q}=$ proportion of failure, $\mathrm{Z}=$ Confidence level (90\%).

\section{Data collection instruments and procedures}

Pre-test structured questionnaire was used to collect information from the women. In this survey scheduled questionnaires were used as most women cannot write and read. Then, three enumerators were selected based on their proficiency in communicating using local language, educational background and prior exposure to similar works. In addition, a structured interview was used to obtain depth data related to challenges and prospects of women entrepreneur in Hawassa, Arab sefar sub-city.

\section{Model specification}

An econometric model was employed to identify core challenges of women entrepreneur in Hawassa city. The logit model can be used when the dependent variable is dichotomous. It specifies a nonlinear functional relationship between the women owning a business or not owning a business and those factors that influence the women entrepreneur. The factors that affect the women entrepreneur are referred to as explanatory or independent variables. This model has a logistic distribution function for the stochastic term (Greene, 2003; Cameron and Trivedi, 2005), and it has been used by some researchers in related studies. Therefore, the 
dependent variable is binary ( 1 for women-owned business and 0 for women not owned business). Let the observed outcome be $\mathrm{Y}$ i and the underlying latent variable $\mathrm{Y}^{*}$, which is the unobserved threshold level that marks between women owns business and women do not own business. It is assumed that this is a function of observed culture, social and economic factors, said $\mathrm{Xi}$, and unobserved characteristics, say $\varepsilon_{i}$, for respondent $\mathrm{i}$. This can be expressed in equation form as below:

$$
Y_{i}=\beta_{0}+\beta_{1} X_{1}+\beta_{2} X_{2}+\beta_{3} X_{3}+\beta_{4} X_{4}+\beta_{5} X_{5}+\ldots \ldots \beta_{n} X_{1 n}+{ }^{8} i
$$

Whereas $Y_{i}=$ indicate dependent Variable (Women entrepreneur),

$\beta_{0=}$ indicate constant term or intercept, $\mathrm{X} 1 \ldots \mathrm{Xn}$ is explanatory variables impedes women entrepreneur which includes education status, training, lack of premises, lack of market and technical skills, etc.

\section{Method of data analysis and processing}

Upon completion of the fieldwork, the women's entrepreneur data was coded, entered into SPSS software Version 20, cleaned, and verified. The logit model was used to see the effect of the independent variable on the outcome variable. In addition, simple descriptive statistics such as percentage and frequency were used to summarize data; tables for display results.

\section{Reliability, validity and ethical consideration}

To test the reliability of the questions, Cronbach's Alpha was used to check for internal consistency. Pilot tests were conducted using a convenience sampling technique to see the validity of the instruments of data collection. The structured questionnaire was prepared in English first, translated to the local language, and again translated back to English to ensure consistency of the questionnaire. Data collectors and supervisors were trained on each item included in the study tools and objectives. During data collection, regular supervision and follow up was made. Investigator also crosschecked for fullness and reliability of the data.

\section{RESULTS}

The women participated in the business for different purposes, which include generating income, desire for autonomy, etc. Accordingly, the majority of the women, 50\% started a business to increase their family income; while the remaining $16.7,31$, and $2.4 \%$ initiated business due to lack of other sources of income, desire for autonomy and unemployment respectively. Hence, most women launched their own business to augment their family income and followed by a desire for independence (Table 1).

Table 1. Reason for starting a business.

\begin{tabular}{|l|c|c|}
\hline \multicolumn{1}{|c|}{ Alternative } & Frequency & Percentage \\
\hline Unemployment & 1 & 2.4 \\
\hline To increase family income & 21 & 50 \\
\hline Lack of other sources of income & 7 & 16.4 \\
\hline Desire for autonomy & 13 & 31 \\
\hline \multicolumn{1}{|c|}{ Total } & 42 & 100 \\
\hline
\end{tabular}

\section{Sources of fund}

The sources of funds are the most critical factor, which hinders women entrepreneurial activities. As a result, the women look for different sources of fund to initiate their own business of which personal saving was $45.2 \%$, followed by borrowing from relatives (23.8\%); whereas the remaining 16.7 and $14.3 \%$ was for borrowing from the bank and traditional institutions (like 'Equb' or 'Idir') respectively (Table 2).

Table 2. Sources of funds.

\begin{tabular}{|l|l|l|}
\hline Sources of funds & Frequency & Percentage \\
\hline Own saving & 19 & 45.2 \\
\hline Borrowing from traditional institutions('Iqub or 'Idir') & 6 & 14.3 \\
\hline Borrowing from relatives & 10 & 23.8 \\
\hline Borrowing from Bank & 7 & 16.7 \\
\hline Total & 42 & 100 \\
\hline
\end{tabular}

\section{Women skills}

The study also found that about $66.7 \%$ of all women entrepreneur lacked marketing skills to execute their business properly, while the remaining 21.4 and $11.9 \%$ did not have sufficient managerial and technical skills respectively. The data obtained from the interview depicted that most of the women did not have inadequate knowledge of the internet to get up-to-date information, ability to make a profitable product, inaccessibility of newspapers and magazines to read and watch some educative television programmes and lack of business experience were the major obstacles of women entrepreneurs in Hawassa city. The study also found that women need managerial, selling and technical skills training support from the government. In addition, providing continuous skill training on record keeping and reporting is indispensable for women entrepreneur success (Table 3). 
Table 3. Women skills.

\begin{tabular}{llll}
\hline Variable & Category & Frequency & Percentage \\
\hline What type of skills do you need & Managerial skill & 9 & 21.4 \\
to run your business? & Marketing skill & 28 & 66.67 \\
& Technical & 5 & 11.9 \\
& Total & 42 & 100.0 \\
\hline
\end{tabular}

\section{Government support}

The government has to encourage women entrepreneur via providing finance, guidance and training. Consequently, almost more than half of the women, 55\% wanted business related training from the government to undertake their own business and followed by experience sharing (19\%), access to credit (17\%) and workplace $(9.5 \%)$ (Table 4).

Table 4. Government support.

\begin{tabular}{|l|l|l|l|}
\hline Variable & Category & Frequency & Percentage \\
\hline \multirow{3}{*}{$\begin{array}{l}\text { What types of support do you } \\
\text { need from government }\end{array}$} & Business-related training & 23 & 54.8 \\
\cline { 2 - 4 } & Experience sharing & 8 & 19.04 \\
\cline { 2 - 4 } & Business working place & 4 & 9.5 \\
\cline { 2 - 4 } & Access to credit & 7 & 16.7 \\
\cline { 2 - 4 } & Total & 42 & 100.0 \\
\hline
\end{tabular}

\section{Prospects of women entrepreneuria}

Women entrepreneurial activities have a positive social and economic impact for both the women and their surrounding environment. It helps women to make an economical choice and change their business idea into profits and employment through improved productions and services. Most women choose to engage in entrepreneur activities, as it does not require a minimum level of education and barrier to enter as a formal sector. The study also showed that about 64.8 replied as women entrepreneur reduced income gaps among men and women and followed by empowering women $(23.8 \%)$ and improving the standard of living of women $(11.9 \%)$. This shows that women entrepreneur shrink income discrepancy between men and women and empowers women to participate in economic, social activities, etc. actively. Also, women entrepreneurial activities assist women to become economically independent and to build high self-esteem. This indicates that women participated in business activities is more economically independent and self-confident than women who do not participate in the business (Table 5).

Table 5. Prospects of women entrepreneur.

\begin{tabular}{|l|l|l|}
\hline The prospects of women entrepreneur & Frequency & Percentage \\
\hline Reduce income gaps in business & 18 & 42.85 \\
\hline Empower women & 14 & 23.8 \\
\hline Increase women standard of living & 9 & 11.9 \\
\hline Total & 42 & 100.0 \\
\hline
\end{tabular}

\section{Factors affecting women entrepreneur in Hawassa, Arab sefar sub city}

The outcomes of multivariate analysis depicted that educational level, market problem, lack of premises, and lack of collateral were strongly associated with women entrepreneur at a p-value less than 0.05 . The results of the study also showed that women who have collateral to access to credit were about four times more likely to participate in business than women who do not have collateral (AOR 3.914 (95\% CI) (0.370-41.394)) (Table 6).

Table 6. Factors affecting women entrepreneur in Hawassa, Arab sefar sub city.

\begin{tabular}{|c|c|c|c|c|c|c|}
\hline \multirow[t]{2}{*}{ Step } & \multirow[t]{2}{*}{ Variable } & \multirow[t]{2}{*}{$\mathrm{B}$} & \multirow[b]{2}{*}{ Sig. } & \multirow[t]{2}{*}{$\operatorname{Exp}(B)$} & \multicolumn{2}{|c|}{ 95.0\% C.I.for $\mathrm{EXP}(\mathrm{B})$} \\
\hline & & & & & Lower & Upper \\
\hline \multirow{9}{*}{$\begin{array}{l}\text { Step } \\
1^{\mathrm{a}}\end{array}$} & Training & .067 & .938 & 1.069 & .199 & 5.742 \\
\hline & Support from government & .712 & .418 & 2.038 & .365 & 11.391 \\
\hline & Lack of premises & 1.370 & $.018 *$ & 3.934 & .512 & 30.231 \\
\hline & Collateral & 1.365 & $.037 *$ & 3.914 & .370 & 41.394 \\
\hline & market problem & -1.996 & $.030 *$ & .136 & .018 & 1.003 \\
\hline & Lack of skills & .932 & .529 & 2.540 & .140 & 46.229 \\
\hline & education level & .281 & $.015^{*}$ & 1.325 & .674 & 2.603 \\
\hline & marital status & .206 & .832 & 1.229 & .184 & 8.231 \\
\hline & Constant & -4.167 & .308 & .016 & & \\
\hline
\end{tabular}

Notes: * $5 \%$ significant level.

\section{DISCUSSION}

The study tried to assess challenges and prospects of women entrepreneur in Hawassa, Arab sefar sub-city. According to findings of this study, majority of the women started their own businesses to increase their family 
income and to improve their family standard of living. It was also found that most women initiated business to enhance their income, lack of employment opportunities and the need for flexible work (Robinson, 2001). The finding of study is also in line with the study conducted on the reasons for starting the business by Hisrich and Brush (1985) as well as Andrew and Ojeka (2011) who found that women start business because of 'push' and 'pull' factors such as interest in the business, to complement their husbands' effort and desire for autonomy. The women's entrepreneur also highly contributed to the economic well-being of the family and communities via poverty reduction and women empowerment (Madhukar, 2016).

The study also depicted that relatively higher proportions of women initiated their own business using their saving. A similar finding was reported by other studies of challenges and prospects in Ethiopia which found personal saving as a primary source of fund for women to initiate their own business (Demeke, 2016). Almost for all women in developing countries, it is tricky for them to access credit service as it requires collateral beyond their capacity. This demonstrated that women access to credit service is more successful than those women do not access to credit.

The finding of this study revealed that about $66.67 \%$ of the women businesses are unsuccessful due to lack of marketing and managerial skills. Carter et al. (2000) stated that most of the women do not have adequate access to marketing skills, market information and professional advice. Moreover, most women do not have sufficient knowledge to use the internet and low profit. Similarly, most of them have inadequate knowledge of computer and Internet activities (Andrew and Ojeka, 2011).

Over half of the women entrepreneur confirmed that having well organized business related training is critical for the success of their businesses. It was also better to have an experience sharing session with those who have plenty of skills and knowledge about the business. The result of this study was similar with a study conducted by (Akinboade, 2015) that women need business related training, experience sharing and awareness creation about their products and services through exhibitions and bazaar to their potential customers. A similar finding also reported by a study undertaken motivating factor for this was to improve their skills, know-how and general competencies, both in areas technically related to their type of business and for business management skills more generally.

Also, there are other factors that impede women entrepreneurs, such as lack of premises, lack of collateral to access credit, market problem, and education levels. The finding of this study also showed that lack of working places (premises) was among factors that impede women entrepreneur success. Accessing appropriate and affordable business premises was also seen as a challenge for business start-up in Ethiopia (Richardson et al., 2004; Desta, 2010). The outcomes of the findings revealed that women could not be able to market their product as they do not have well-built business networking and exploitation by intermediaries.

The result of the current survey disclosed that poor educational background was one of the hindering factors of women entrepreneur. This may also be due to primary education they obtained, which is not enough to help them to gain any ground in the business world. Furthermore, another major challenge that women entrepreneurs face is lack of inaccessibility to enough capital to start up their business because formal financial institutions require collateral, which is beyond the capacity of the women. Shaw et al. (2001) similarly suggest that women are less likely to have generated a credit record of accomplishment to establish formal creditworthiness than their male counterparts are.

\section{Conclusion}

Women entrepreneurs play an essential role in the economy. Despite their role, the women entrepreneur was impeded by many factors, which include lack of collateral to access to credit, poor educational background, market problem and lack of premises. Most of women business in Hawassa city also failed due to the lack of compulsory skills, which include marketing and managerial skills. On the other side, reducing income inequality between men and women, empowering women and improving women standard of living were among prospects of women entrepreneur in Hawassa, Arab Sefar Sub City. Thus, it is vital to have excellent managerial and marketing skills, a good scheme that enables women to access credit, and well-built business network to be a success in business.

\section{CONFLICT OF INTERESTS}

The authors have not declared any conflict of interests.

\section{REFERENCES}

Akinboade OA (2014). Regulation, SMEs' growth and performance in Cameroon's central and littoral provinces' manufacturing and retail sectors. African Development Review 26:597-609.

Amha W (2002). The role of finance and business development service (BDS) in micro and small enterprise (MSE) development in Ethiopia. Association of Ethiopian Microfinance Institutions, Ethiopia. Available at: https:/www.worldcat.org/title/role-of-finance-and-businessdevelopment-service-bds-in-micro-and-small- 
enterprise-msedevelopment-in-ethiopia/oclc/53620456.

Andrew ET, Ojeka IU (2011). Problems, Challenges and Prospects of Female Entrepreneurs in Gwagwalada, Abuja. An International MultiDisciplinary Journal 5(3):226-246. Bekele E, Worku Z (2008). Factors that affect the long-term survival of micro, small and medium enterprises in Ethiopia. South African Journal of Economics 76(3): 548-568.

Cameron C, Trivedi P (2005). Macro Econometrics: Methods and Applications (First ed.). Cambridge: Cambridge University Press.

Carter S, Anderson S, Shaw E (2000). Women's business ownership: A review of the academic, popular and internet literature with a UK policy focus. ARPENT: Annual Review of Progress in Entrepreneurship 1:66.

Demeke T (2016). Assessment of challenges and opportunities of women owned micro and small enterprises: A case of Asella town. International Journal of Management, IT and Engineering 6(12):3758.

Gorgievski MJ, Ascalon ME, Stephan U (2011). Small business owners' success criteria, a values approach to personal differences. Journal of Small Business Management 49(2):207-232.

Greene WH (2003). Econometric analysis. Pearson Education India. New York University press.

Hisrich RD, Brush CG (1985). Women and minority entrepreneurs: A comparative analysis. Frontiers of entrepreneurship research. P 566.

Nasima MS, Alam N (2014). Women Micro-Entrepreneurs in Bangladesh: Socio-Economic Aspects and Factors Affecting Their Development. Journal of Business and Technology (Dhaka) 9(1):5370.

Robinson M (2001). The microfinance revolution: Sustainable finance for the poor. The World Bank.

Saravanan D, M ohideen OH, Seid M (2014). Challenges and prospects of women entrepreneur's in Ethiopia. Unpublished

Sonfield A, Hasstedt K, Kavanaugh ML, Anderson R (2013). The social and economic benefits of women's ability to determine whether and when to have children. New York: Guttmacher Institute.

Ulusay de Groot T (2001). Women entrepreneurship development in selected African countries. Private Sector Development (PSD) Technical Working Paper Series-Working Paper 7.

Vossenberg S (2013). Women Entrepreneurship Promotion in Developing Countries: What explains the gender gap in entrepreneurship and how to close it. Maastricht School of Management Working Paper Series 8:127.

Zewde and Associates (2002). Jobs, gender and small enterprises in Africa: preliminary report on women entrepreneurs in Ethiopia. ILO: Addis Ababa. Available at: https://www.microfinancegateway.org/sites/default/files/mfg-enpaper-women-entrepreneurs-in-ethiopia2002.pdf 